\title{
Impacts of organic soil amendments on forage grass production under different soil conditions
}

\author{
${ }^{1}$ Tomas Persson, ${ }^{2}$ Wieslaw Szulc, ${ }^{2}$ Beata Rutkowska, ${ }^{1}$ Mats Höglind, ${ }^{1}$ Hans Martin Hanslin and ${ }^{1}$ Arne Sæb $\varnothing$ \\ ${ }^{1}$ Norwegian Institute of Bioeconomy Research (NIBIO), Særheim, Norway \\ ${ }^{2}$ Warsaw University of Life Sciences-SGGW, Warsaw, Poland \\ e-mail: tomas.persson@nibio.no
}

\begin{abstract}
Organic amendments can improve grassland productivity. Timothy and tall fescue were sown on a sandy loam and a coarse sand at Særheim, Norway, in September 2016 and on a loamy sand at Skierniewice, Poland, in April 2017, and cut and fertilised according to normal practices for the two regions from 2017 to 2019. At both sites, $0.75 \mathrm{~kg}$

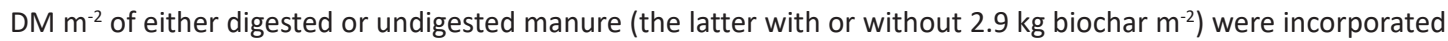
prior to sowing. On the coarse sand at Særheim, total seasonal tall fescue yield in 2018 was $46-60 \%$ higher in the organic amendment treatments, and total seasonal timothy yield in the digestate treatment was $97 \%$ higher, than in the control treatment for the same species with only mineral fertiliser. On the sandy loam at Særheim and the loamy sand at Skierniewice, none of the amendments resulted in significant yield increments. These results indicate a clear effect on soil type on grassland biomass response to organic amendments.
\end{abstract}

Key words: nitrogen, organic fertilisers, plant nutrients, tall fescue, timothy

\section{Introduction}

Forage grasses, which are often the main feedstuff for ruminants (Fulkerson et al. 2007, Thornton 2010), require an adequate nutrient supply, which in many cases is provided by a combination of animal manure and mineral fertiliser (Webb et al. 2010, Gundersen and Heldal 2015). Nutrients in manure and other organic materials are largely bound in organic compounds and need to be mineralised before they can be taken up by plants (Schröder 2005, Thomsen 2005, Sosulski et al. 2013). Anaerobic digestion of manure and other organic materials to produce methane for electricity and heating (Nguyen and Hermansen 2015) affects the nutrient content and availability of these materials. Digestate, the nutrient-rich residues after anaerobic digestion of organic materials of various origin to generate methane, differs from its undigested counterpart in having a markedly lower content of total organic carbon and volatile solids and a higher nitrogen content $(\mathrm{N})$ as a result of the reduced carbon content (C) (Tambone et al. 2010, Losak et al. 2014). Digestate can be separated into wet and dry fractions (Al Seadi et al. 2013). The solid fraction has higher content of phosphorus (P) per unit dry matter, a lower content of $\mathrm{N}$ and potassium (K) and a higher carbon to nitrogen ratio (C/N) than the liquid fraction (Möller and Müller 2012). Pyrolysis and gasification, which are other ways to treat organic matter, also affect the properties of the organic matter. The C-rich porous biochar produced in these processes (Manyà 2012) can be incorporated into soils to improve their water and nutrient retention ability (Biederman and Harpole 2013) and to sequester C (Lehmann et al. 2006).

Soil turnover of $\mathrm{N}$ present in organic compounds is affected by the chemical composition of the organic material (Masunga et al. 2016). A previous study on fertiliser application to perennial ryegrass (Lolium perenne) under controlled greenhouse conditions showed higher shoot biomass yield in plants receiving digestate than in plants receiving undigested slurry, and higher or equal yield compared with plants receiving corresponding amounts of $\mathrm{N}$ as mineral fertiliser (Walsh et al. 2012). The same study showed lower nitrate and ammonium leaching from pots with soils to which liquid digestate and undigested slurry had been added than from pots with soils to which mineral fertiliser had been added (Walsh et al. 2012). Regarding biochar application to agricultural soils, a meta-analysis of previous studies revealed small positive effects on crop productivity, with the largest positive effects on coarse-textured soils and under low pH conditions, albeit with large variation between biochar products of different origin (Jeffery et al. 2011). Biochar originating from poultry litter, wastewater sludge and various wood products all showed positive effects, while biochar originating from biosolids (stabilised organic solids from sewage treatment) had a negative effect (Jeffery et al. 2011). Similar variations in the effects on soil and plants of biochars of different origin were observed by Marmiroli et al. (2018). Schimmelpfenning et al. (2014) showed that, under controlled greenhouse conditions, incorporation of biochar together with pig slurry resulted in $29 \%$ higher shoot biomass yield of perennial ryegrass compared with pig slurry only, possibly because of increased $\mathrm{N}$ retention. Other reported effects of organic amendments include increased soil water retention after application of composted hog manure on a coarse textured soil (Zebarth et al. 1999), and increased soil water holding capacity after biochar incorporation in a silt loam (Karhu et al. 2011). 


\section{AGRICULTURAL AND FOOD SCIENCE}

T. Persson et al. (2020) 29: 482-493

Mineralisation of organically bound N (Cameron et al. 2013), N leaching and volatilization (Valkama et al. 2015) are also affected by soil physical and chemical properties, and climate conditions (Fu et al. 2017). Nutrient uptake also varies between grass species. The $\mathrm{N}$ yield of tall fescue (Festuca arundinacea) was higher than the amount of $\mathrm{N}$ supplied, whereas the $\mathrm{N}$ yield of timothy (Phleum pratense) and a range of other species was lower than the $\mathrm{N}$ supplied by fertilisers (Maire et al. 2009). Also the potential to take up and use $P$ varies between temperate forage grasses (Simpson et al. 2014) as well as with soil type, $\mathrm{pH}$ and initial $\mathrm{P}$ status of the soil the grass ley is grown on (Valkama et al. 2016).

More knowledge about the effects of organic amendments on forage grass productivity is needed, particularly in regions with high densities of ruminants and large flows of nutrients. Studies examining the effects of organic materials that have been subject to different pre-treatments on soil functions and yield in intensive forage grass systems on different soil types can help obtain such knowledge. The aim of this study was to determine the effect of different organic amendments (digested manure, undigested manure, and undigested manure + biochar) on the biomass yield of two forage grasses, timothy and tall fescue, under intensive production conditions at two locations, Særheim, Norway and Skierniewice, Poland with contrasting soil and climate conditions. The effects of the organic amendments on soil organic matter, $\mathrm{N}, \mathrm{P}$ and $\mathrm{K}$ content were also determined.

\section{Materials and methods}

\section{Experimental locations, and stand establishment and management}

Field experiments were established at Særheim, Norway $\left(58^{\circ} 46^{\prime} \mathrm{N}, 5^{\circ} 39^{\prime} \mathrm{E}, 90 \mathrm{~m}\right.$ asl), and Skierniewice, Poland ( $51^{\circ} 57^{\prime}$ $\mathrm{N}, 20^{\circ} 9^{\prime} \mathrm{E}, 128 \mathrm{~m}$ asl) (Table 1). The mean annual temperature is $8.0^{\circ} \mathrm{C}$ at Særheim and $8.6^{\circ} \mathrm{C}$ at Skierniewice, and mean accumulated annual precipitation is $1392 \mathrm{~mm}$ and $538 \mathrm{~mm}$, respectively for the last 30 years. At the former site, the experiment was conducted on one sandy loam soil (the original soil at the site), which contained organic material and plant nutrients in amounts typical for agricultural soils in the region which reflects a historical high supply of animal manure, and one coarse sand soil with low amounts of organic material and plant nutrients (Table 1).

Table 1. Organic matter, Kjeldahl nitrogen (TN), ammonium- $\mathrm{N}\left(\mathrm{NH}_{4}-\mathrm{N}\right)$, nitrate- $\mathrm{N}\left(\mathrm{NO}_{3}-\mathrm{N}\right)$ and plant-available phosphorus $(\mathrm{P}-\mathrm{AL})$ and potassium (K-AL) in the upper $25 \mathrm{~cm}$ soil layer, and type of species in the field experiments

\begin{tabular}{|c|c|c|}
\hline Soil texture & Initial soil organic matter and nutrient content & Species and mixtures of species \\
\hline \multicolumn{3}{|l|}{ Særheim, Norway } \\
\hline $\begin{array}{l}\text { Sandy loam } \\
\text { ( } 65 \% \text { sand, } 26 \% \text { silt, } 9 \% \text { clay) }\end{array}$ & $\begin{array}{l}\text { Soil organic matter (SOM): } 6.7 \text { DM\% } \\
\text { Kjeldahl-N (TN): } 1.6 \mathrm{~g} \mathrm{~kg}^{-1} \mathrm{DM} \\
\mathrm{NH}_{4}-\mathrm{N}: 5.9 \mathrm{mg} \mathrm{kg}^{-1} \mathrm{DM} \\
\mathrm{NO}_{3}-\mathrm{N}: 11.7 \mathrm{mg} \mathrm{kg}^{-1} \mathrm{DM} \\
\mathrm{P}-\mathrm{AL}: 49.5 \mathrm{mg} \mathrm{kg}^{-1} \mathrm{DM} \\
\mathrm{K}-\mathrm{AL}: 150 \mathrm{mg} \mathrm{kg}^{-1} \mathrm{DM}\end{array}$ & $\begin{array}{l}\text { 1) Tall fescue cv. Swaj } \\
\text { 2) Timothy cv. Grindstad }\end{array}$ \\
\hline $\begin{array}{l}\text { Coarse sand } \\
\text { ( } 92 \% \text { sand, } 4 \% \text { silt, } 4 \% \text { clay) }\end{array}$ & $\begin{array}{l}\text { SOM: } 1.0 \text { DM\% } \\
\text { Kjeldahl-N (TN): } 0.10 \mathrm{~g} \mathrm{~kg}^{-1} \mathrm{DM} \\
\mathrm{NH}_{4}-\mathrm{N}: 0.72 \mathrm{mg} \mathrm{kg}^{-1} \mathrm{DM} \\
\mathrm{NO}_{3}-\mathrm{N}: 0.86 \mathrm{mg} \mathrm{kg}^{-1} \mathrm{DM} \\
\mathrm{P}-\mathrm{AL}:<20 \mathrm{mg} \mathrm{kg}^{-1} \mathrm{DM} \\
\mathrm{K}-\mathrm{AL}: 32 \mathrm{mg} \mathrm{kg}^{-1} \mathrm{DM}\end{array}$ & $\begin{array}{l}\text { 1) Tall fescue cv. Swaj } \\
\text { 2) Timothy cv. Grindstad }\end{array}$ \\
\hline \multicolumn{3}{|l|}{ Skierniewice, Poland } \\
\hline $\begin{array}{l}\text { Loamy sand } \\
\text { ( } 65 \% \text { sand, } 18 \% \text { silt, } 16 \% \text { clay) }\end{array}$ & $\begin{array}{l}\text { SOM: } 1.4 \mathrm{DM} \% \\
\text { Kjeldahl-N (TN): } 0.40 \mathrm{~g} \mathrm{~kg}^{-1} \mathrm{DM} \\
\text { P-AL: } 14.6 \mathrm{mg} \mathrm{kg}^{-1} \mathrm{DM} \\
\mathrm{K}-\mathrm{AL}: 62.4 \mathrm{mg} \mathrm{kg}^{-1} \mathrm{DM}\end{array}$ & $\begin{array}{l}\text { 1) Tall fescue cv. Kora } \\
\text { 2) Timothy cv. Orlica } \\
\text { 3) } 50 \% \text { tall fescue cv. Kora- } 50 \% \text { timothy } \\
\text { cv. Orlica (seed weight basis) }\end{array}$ \\
\hline
\end{tabular}

The latter soil was transported from a glacial till deposit approximately $5 \mathrm{~km}$ northwest $\left(58^{\circ} 47^{\prime} \mathrm{N} ; 5^{\circ} 35^{\prime} \mathrm{E}, 14 \mathrm{~m}\right.$ asl) of the experimental site and replaced the upper $25 \mathrm{~cm}$ of the original soil at the experimental site. The transported soil had not been used previously for plant production and was thus not affected by earlier agricultural practices. At Særheim, timothy grass (Phleum pratense cv. Grindstad) and tall fescue (Festuca arundinacea cv. Swaj) were sown in pure stands at a seed density of $3.5 \mathrm{~g} \mathrm{~m}^{-2}$ on 8 September 2016. These grass swards were cut during the season in 2017-2019 and samples were dried to determine dry matter yield as described below. Due to poor germination in autumn 2016, resulting in a sparse and uneven stand in the following spring, an additional sowing was carried out on 19 April 2017 with the same seed density to ensure an even stand. To facilitate germination and establishment, the field was irrigated with approximately $20 \mathrm{~mm}$ shortly after sowing in 2017. 


\section{AGRICULTURAL AND FOOD SCIENCE}

T. Persson et al. (2020) 29: 482-493

Before sowing, organic amendments (see section Organic amendment characteristics and application below and Table 4 for details of their properties) were manually distributed evenly over plots in three different treatments and then incorporated into the upper $25 \mathrm{~cm}$ soil layer by a rotor harrow on 5 September 2016 within a couple of hours after the application. A control treatment with no organic amendments was also established. The experiment had a split-plot design, with soils as randomised main plots (main-plot factor) and soil amendment treatments and species completely randomised within each main plot as split-plot factors. Each combination of soil, species and treatment was replicated four times. The total size of each subplot was $24 \mathrm{~m} \times 7 \mathrm{~m}$. This area was divided into $3 \mathrm{~m} \times 7 \mathrm{~m}$ areas for each combination of species and soil amendment treatment.

At Skierniewice, timothy (cv. Orlica) and tall fescue (cv. Kora) were sown on 14 April 2017, at a seed density of 4.0 $\mathrm{g} \mathrm{m}^{-2}$. In addition, a mixture of $50 \%$ timothy- $50 \%$ tall fescue on a seed weight basis was sown at the same seed density as in the monoculture plots. On 8 April 2017, organic amendments (see below for details) similar to those used at Særheim were manually distributed evenly across the experimental plots and manually incorporated into the upper $25 \mathrm{~cm}$ soil layer within an hour after the distribution. The experiment was conducted on a loamy sand soil (Table 1), which had not received any mineral or organic fertilizers for 20 years. Each species and species mixture were sown in separate adjacent sections of the experimental field within which amendment treatments were replicated in four blocks. Each of the block had an area of $18 \mathrm{~m} \times 6 \mathrm{~m}$ divided into $4.5 \mathrm{~m} \times 1.5 \mathrm{~m}$ areas for each combination of species or species mixture and soil amendment. Due to infestation of barnyard grass (Echinochloa crus-galli) in more than $80 \%$ of the experimental area, the whole area was ploughed under in June following a cut on 25 May for which biomass was not recorded. The same grass species and mixtures as in the original plan were re-sown on 16 July 2017, at the same seed density as in April.

At both locations, mineral fertiliser was applied at the beginning of each growing season and after each cut. At Særheim small amounts of mineral fertilisers were also applied at sowing in September 2016 to enhance establishment (Table 2).

Table 2. Content of nitrogen (N), phosphorus (P) and potassium (K) in applied mineral fertilizers $\left(\mathrm{kg} \mathrm{ha}^{-1}\right)$

\begin{tabular}{|c|c|c|c|}
\hline Application date & $\mathrm{N}$ & $\mathrm{P}$ & $\mathrm{K}$ \\
\hline \multicolumn{4}{|l|}{ Særheim, sandy loam } \\
\hline 20 September, 2016 & 31 & 5 & 26 \\
\hline 4 May, 2017 & 80 & 9 & 36 \\
\hline 26 June, 2017 & 50 & 5.6 & 22.5 \\
\hline 11 August, 2017 & 50 & 5.6 & 22.5 \\
\hline 23 April, 2018 & 120 & 14 & 59 \\
\hline 5 June, 2018 & 100 & 12 & 49 \\
\hline 2 August, 2018 & 100 & 12 & 49 \\
\hline 17 April, 2019 & 120 & 14 & 59 \\
\hline \multicolumn{4}{|l|}{ Særheim, coarse sand } \\
\hline 20 September, 2016 & 31 & 5 & 26 \\
\hline 4 May, 2017 & 80 & 12 & 48 \\
\hline 26 June, 2017 & 50 & 7.5 & 30 \\
\hline 11 August, 2017 & 50 & 7.5 & 30 \\
\hline 23 April, 2018 & 120 & 20 & 100 \\
\hline 5 June, 2018 & 100 & 12 & 49 \\
\hline 2 August, 2018 & 100 & 12 & 49 \\
\hline 17 April, 2019 & 120 & 20 & 100 \\
\hline \multicolumn{4}{|l|}{ Skierniewice } \\
\hline 25 April, 2017 & 50 & 10 & 52 \\
\hline 28 April, 2018 & 80 & 53 & 60 \\
\hline 6 June, 2018 & 40 & 12 & 40 \\
\hline 20 April, 2019 & 80 & 53 & 60 \\
\hline 25 June, 2019 & 40 & 12 & 40 \\
\hline
\end{tabular}




\section{AGRICULTURAL AND FOOD SCIENCE}

T. Persson et al. (2020) 29: 482-493

Mineral fertilisers applied in Særheim were manufactured by Grupa Azoty, Zakłady Azotowe "Puławy" S.A., Gdańskie Zakłady Nawozów Fos-forowych "Fosfory" Sp. z o.o. and Bialchem Group Sp. Z o.o., Poland. The application rates were based on regional recommendations for grass leys at the two locations and differences in expected biomass between ley years. The rates were also adjusted to the plant-available P and K content of the soil according to soil analyses carried out at the beginning of each growing season. The weather conditions during the summer of 2018 were extremely dry, both at Særheim and at Skierniewice, and the experiments required irrigation on several occasions to prevent plant death during long periods without precipitation and to enable nutrient infiltration into the soil. At Særheim, the coarse sand was first irrigated with approximately $50 \mathrm{~mm}$ of water on 24-27 May, and both soils were irrigated with approximately $15 \mathrm{~mm}$ on 5-7 June, $20 \mathrm{~mm}$ on 2-5 July and $30 \mathrm{~mm}$ on 19-25 July. The whole experimental area at Skierniewice was irrigated with approximately $20 \mathrm{~mm}$ on 24-27 May, $10 \mathrm{~mm}$ on 10-12 June, $15 \mathrm{~mm}$ on 7-10 July and $30 \mathrm{~mm}$ on 25-28 July.

\section{Organic amendment characteristics and application}

Soils at Særheim and Skierniewice, were analysed for organic matter (SOM), N, P and K content at the start of the experiment (Table 1), and then at the start of the growing season in March 2018 and 2019 for each soil and amendment combination, across species. Total soil N was analysed using the Kjeldahl-N method (EN 13654-1) and $\mathrm{P}$ and $\mathrm{K}$ content using the ammonium lactate ( $\mathrm{P}-\mathrm{AL}$ and $\mathrm{K}-\mathrm{AL}$ ) method (Egnér et al. 1960). The experimental treatments comprised three organic amendments and a control treatment with no organic amendment application (Table 3). In the soils at Særheim, the organic soil amendments consisted of $0.75 \mathrm{~kg} \mathrm{~m}^{-2} \mathrm{DM}$ of the dry fraction of dry/wet separated pig manure, $0.75 \mathrm{~kg} \mathrm{~m}^{-2} \mathrm{DM}$ anaerobically digested dry fraction of the pig manure, and 0.75 $\mathrm{kg} \mathrm{m}^{-2} \mathrm{DM}$ pig manure $+2.87 \mathrm{~kg} \mathrm{~m}^{-2}$ wood-based biochar that was not supplemented with any plant nutrients. The total amount of nutrients and organic carbon applied in each treatment is shown in Table 3 and the chemical properties of the amendments in Table 4. The amounts of manure and digestate applied were within the range of manure doses normally applied to grass leys in south-western Norway in August-September, which are limited by regulations on P dose per unit area (Ministry of Agriculture and Food et al. 2002). The amount of biochar applied was in the middle of the recommended range to improve soil C content and productivity (Major 2010). At Skierniewice, cattle farm manure, i.e. the solid and liquid fraction, and straw, was used instead of pig manure, at the same rates as at Særheim, and the biochar used was of coniferous wood origin, which naturally contained some $\mathrm{N}$ (Table 4) but was not supplemented with any additional plant nutrients.

\begin{tabular}{|c|c|c|c|c|c|}
\hline Application date & & Corg & $\mathrm{N}$ & $\mathrm{P}$ & $\mathrm{K}$ \\
\hline \multicolumn{6}{|l|}{ Særheim, both soils } \\
\hline \multirow[t]{4}{*}{5 September 2016} & Pig manure & 3150 & 263 & 143 & 67.5 \\
\hline & Digestate & 2108 & 57 & 76.5 & 30.8 \\
\hline & Pig manure + biochar & 42120 & 263 & 143 & 67.5 \\
\hline & Control & - & - & - & - \\
\hline \multicolumn{6}{|l|}{ Skierniewice } \\
\hline \multirow[t]{4}{*}{15 September 2016} & Cattle manure & 2400 & 168 & 42.8 & 193 \\
\hline & Digestate & 3728 & 446 & 30.0 & 202 \\
\hline & Cattle manure + biochar & 38500 & 168 & 42.8 & 193 \\
\hline & Control & - & - & - & - \\
\hline
\end{tabular}

Table 4. Nutrient and organic carbon (Corg) content ( $\left.\mathrm{g} \mathrm{kg}^{-1} \mathrm{DM}\right)$ of the organic amendments used in field experiments

\begin{tabular}{lllll}
\hline & $\mathrm{N}$ & $\mathrm{P}$ & $\mathrm{K}$ & $\mathrm{C}$ \\
\hline Særheim & & & & 420 \\
Pig manure & 35.1 & 19.1 & 9.0 & 281 \\
Digestate from pig manure & 7.6 & 10.2 & 4.1 & 743 \\
Biochar & - & - & - & 320 \\
Skierniewice & & & 25.7 & 497 \\
Cattle manure & 22.4 & 5.7 & 26.9 & 610 \\
Digestate from cattle manure & 59.5 & 4.00 & - & \\
Biochar & 4.8 & - & & \\
\hline
\end{tabular}




\section{AGRICULTURAL AND FOOD SCIENCE}

\section{Soil water-holding capacity}

To obtain information on whether any observed effects of the amendment on plant productivity were related to soil water-holding capacity rather than soil nutrients, the effect of the organic amendments on soil water-holding capacity was determined gravimetrically under laboratory conditions according to Reynolds (1970) for the two soils at Særheim, which represented the full texture range of the three experimental soils. Samples of these two soils taken from the upper $25 \mathrm{~cm}$ layer were mixed with organic amendments at the same ratios as used in the Særheim field experiment and the mixtures were placed in glass funnels covered with filter paper (two samples per treatment). Control samples with soils without organic amendments were placed in similar funnels. No mineral fertiliser was added to the soils, based on the assumption that mineral fertilisers have no direct effect on soil water-holding capacity. Water was added to the funnels until the mixtures were saturated and then the funnels were covered with plastic film to minimise evaporation and allowed to drain for 12 hours. Subsamples of the drained samples were weighed, dried at $105^{\circ} \mathrm{C}$ for approximately 36 hours and weighed again. Subsamples were considered completely dry when their weight did not decrease after additional drying. Soil water content after free drainage was then calculated as:

$M C=\left(m_{\text {moist_soil }}-m_{\text {dry_soil }} / m_{\text {dry_soil }}\right) / m_{\text {dry_soil }} \times 100$

where $\mathrm{MC}$ is soil water content (weight\%), $\mathrm{m}_{\text {moist_soil }}$ is the weight of the moist soil after free drainage and $m_{\text {dry_soil }}$ is the weight of the soil after drying.

\section{Cutting regimes and dry-matter determination}

In 2017, the plots on the sandy loam at Særheim were cut on 6 June, and those on the coarse sand on 15 June, to a stubble height of $5 \mathrm{~cm}$. Due to low biomass production, this yield was not recorded. A second cut to the same stubble height as in the first cut was carried out on 8 August in all plots. Samples of cut biomass were dried at 60 ${ }^{\circ} \mathrm{C}$ for at least 48 hours and weighed. In 2018, the plots were cut to $5 \mathrm{~cm}$ stubble height on 29 May, 17 July and 30 September, when the plants were in mid-heading stage. In 2019, one cut was performed on 5 June, before the experiment was terminated.

At Skierniewice, the plots were cut at mid-heading stage to $5 \mathrm{~cm}$ stubble height on 10 August 2017, but biomass was not recorded. In 2018, the plots were cut to $5 \mathrm{~cm}$ stubble height on 6 June, 13 July and 13 August, when the plants were in mid-heading stage. In 2019, the plots were cut to $5 \mathrm{~cm}$ stubble height on 25 June and 10 October. Biomass samples from all treatment plots were dried at $60^{\circ} \mathrm{C}$ for at least 48 hours and weighed after all cuts.

\section{Statistical analysis}

For Særheim, differences in fitted means (least square means) in above-ground dry matter yield between species, organic amendment treatments, and any interactions between these factors were analysed with the Proc GLIMMIX function of SAS v. 9.4 (SAS Institute Inc., Cary, NC, USA). This procedure enabled species, amendment treatment and soil to be treated as fixed class variables, and main plot and main plot by soil interactions as random class variables. In Skierniewice, each species was cultivated in separate section of the experimental field. Consequently, we analysed each species separately for this site without performing any analysis of species and organic amendment treatment interactions at this site.

Pairwise comparisons of factor levels were made using the Tukey-Kramer method and the Sattertwaite method was used to approximate the number of degrees of freedom for the mean and pairwise comparisons for both locations. These analyses were carried out for each cut separately and for the total yield of all cuts during each season. Differences in Kjeldahl-N (total N; TN), ammonium- $\mathrm{N}\left(\mathrm{NH}_{4}-\mathrm{N}\right)$ and nitrate- $\mathrm{N}\left(\mathrm{NO}_{3}-\mathrm{N}\right)$, soil organic matter, P-AL and K-AL in the upper $25 \mathrm{~cm}$ layer of the two soils at Særheim at the start of the experiment in September 2016 were analysed with the Proc TTEST function of SAS v. 9.4. Differences in soil nutrients and organic matter between soils, amendments and soil and amendment interactions after the start of the experiment, as well as differences in soil water content between amendments were analysed with the Proc GLIMMIX function of SAS v. 9.4, setting soil as a random variable. 


\section{Results \\ Species differences}

At Særheim, there were significant interactions between soil and species $(p<0.05)$ on yield of all cuts in August, on total seasonal yield in 2018 and on first-cut yield in 2019. For most cuts and for total seasonal yield in 2018 (Fig. 1), the yield difference between tall fescue, which produced the largest amount of biomass on both Særheim soils, and timothy was greater on the coarse sand soil than on the sandy loam. Therefore, we subsequently analysed differences between species for each soil separately.

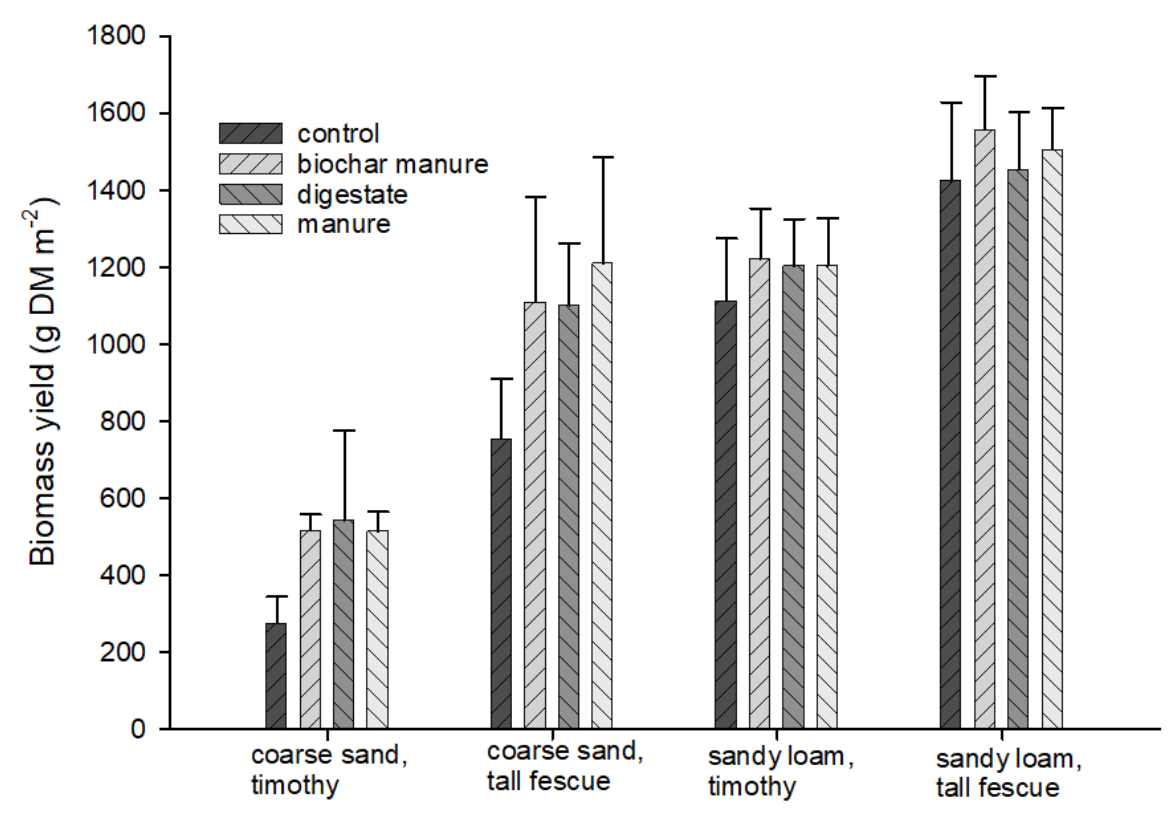

Fig. 1. Total seasonal dry matter yield of timothy and tall fescue on the two experimental soils at Særheim, Norway, in 2018. Error bars indicate 95\% confidence interval.

\section{Amendment effects on biomass}

At Særheim, there were no statistically significant interactions between species and amendment treatments for any of the cuts across the three years, or for total seasonal yield in 2018. However, there were statistically significant interactions $(p<0.05)$ between soils and treatments for third-cut yield and for total seasonal yield in 2018 , with significant differences between the treatments with organic amendments and the treatment with only mineral fertiliser on the coarse sand soil. Therefore, we subsequently analysed the effects of the amendments separately per soil and, since there was a consistent species-soil interaction, also per species.

On the coarse sand at Særheim, total seasonal biomass yield of tall fescue in 2018 was significantly $(p<0.05)$ higher in all the organic amendment treatments, while total seasonal yield of timothy was higher in the digestate treatment than in the corresponding control treatments that only received mineral fertiliser. In 2018, on the coarse sand there was a tendency for greater differences in first- and second-cut yield than in third-cut yield (both species) between all organic amendment treatments and the mineral fertiliser control (Fig. 2). For the first- and third-cut tall fescue on the same soil, the yield in the manure treatment was significantly higher than in the mineral fertiliser control. The third-cut timothy yield in the manure and manure + biochar treatments on the coarse sand was significantly higher than in the mineral fertiliser control on the same soil (results not shown). At Skierniewice, in 2018 and in 2019 there were no statistically significant differences in biomass between amendment treatments for any of the cuts or for total seasonal yield in any of the species (Fig. 3 and Fig. 4). 


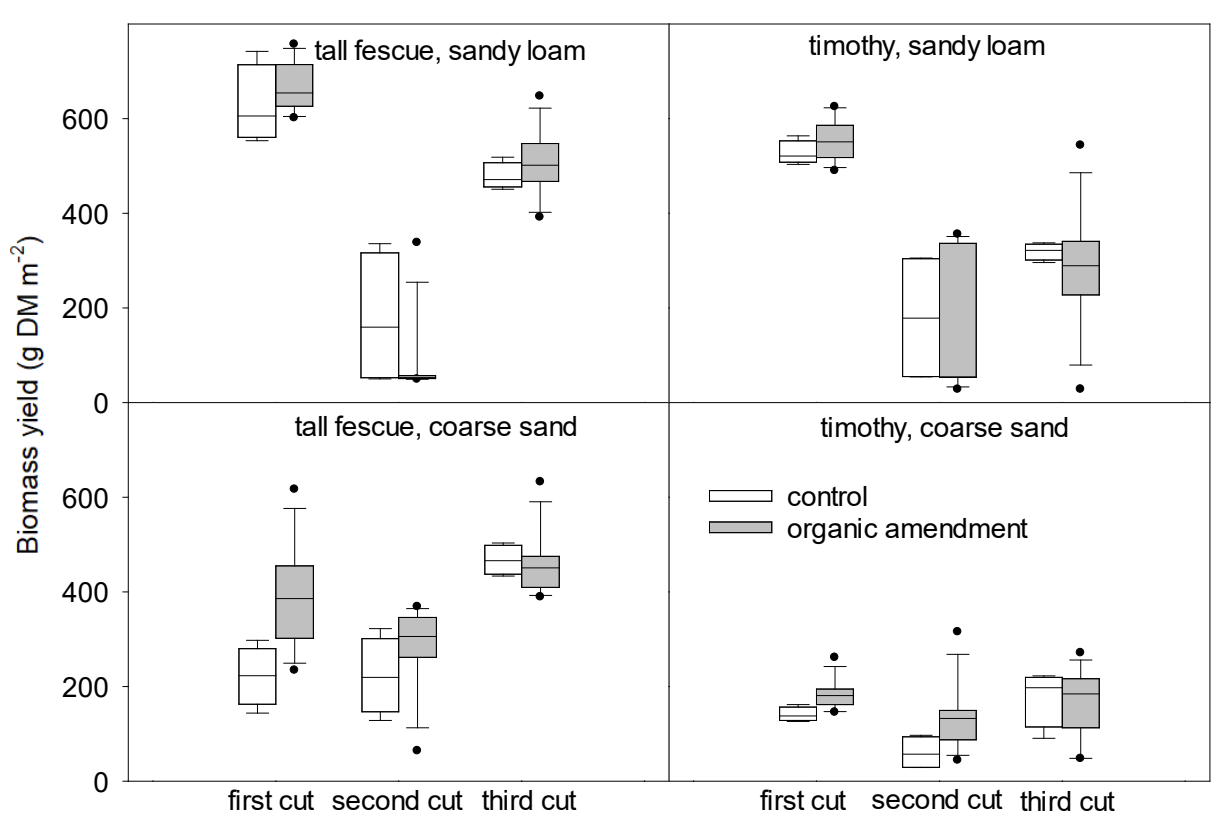

Fig. 2. Mean yield in the organic amendment treatments in comparison with the control treatment for the three cuts in 2018 at Særheim, Norway

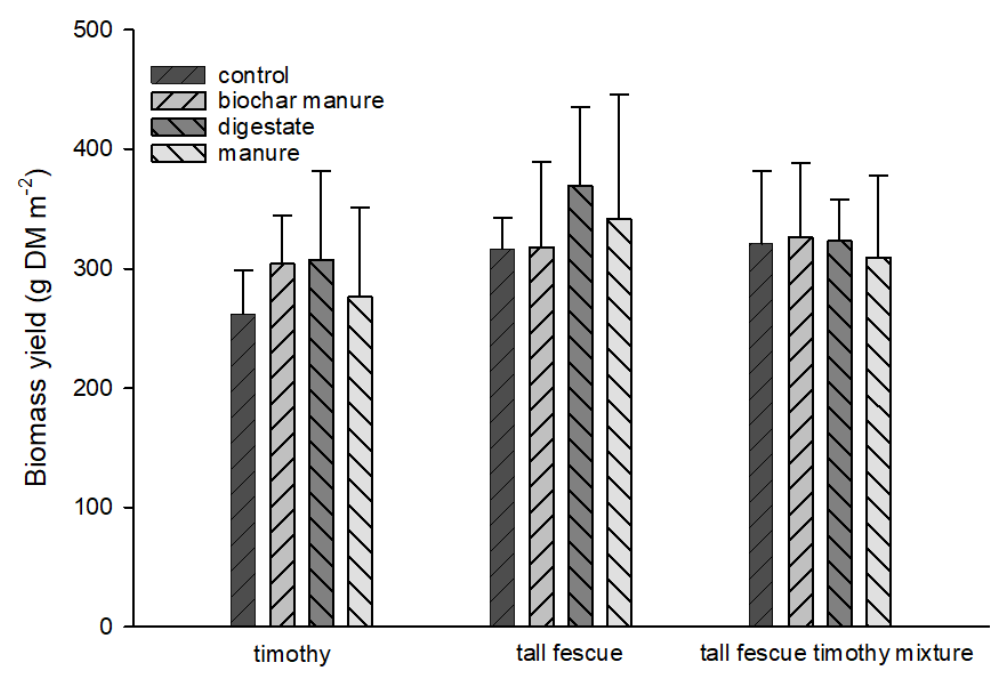

Fig. 3. Seasonal biomass yield of timothy, tall fescue and a timothy-tall fescue mixture in the four treatments at Skierniewice, Poland, in 2018. Error bars indicate $95 \%$ confidence interval.

\section{Soil nutrients and water-holding capacity}

At the start of the experiment at Særheim, in September 2016, there were significantly higher concentrations of TN, $\mathrm{NH}_{4}-\mathrm{N}$ and $\mathrm{NO}_{3}-\mathrm{N}, \mathrm{SOM}, \mathrm{P}-\mathrm{AL}$ and $\mathrm{K}-\mathrm{AL}$ in the sandy loam soil than in the coarse sand soil (Table 1). The amount of TN continued to be higher in the sandy loam than in the coarse sand throughout the experimental period for most amendment treatments. The amount of $\mathrm{NH}_{4}-\mathrm{N}$ remained higher in the sandy loam than in the coarse sand until 2018 but there were no statistically significant between the two soils for any of the amendment treatments in 2019. The difference in $\mathrm{NO}_{3}-\mathrm{N}$ varied between soils and amendments (Table 5 and 6). However, there were no statistically significant differences in $\mathrm{NH}_{4}-\mathrm{N}, \mathrm{NO}_{3}-\mathrm{N}$ or TN between amendment treatments within soils. 


\section{AGRICULTURAL AND FOOD SCIENCE}

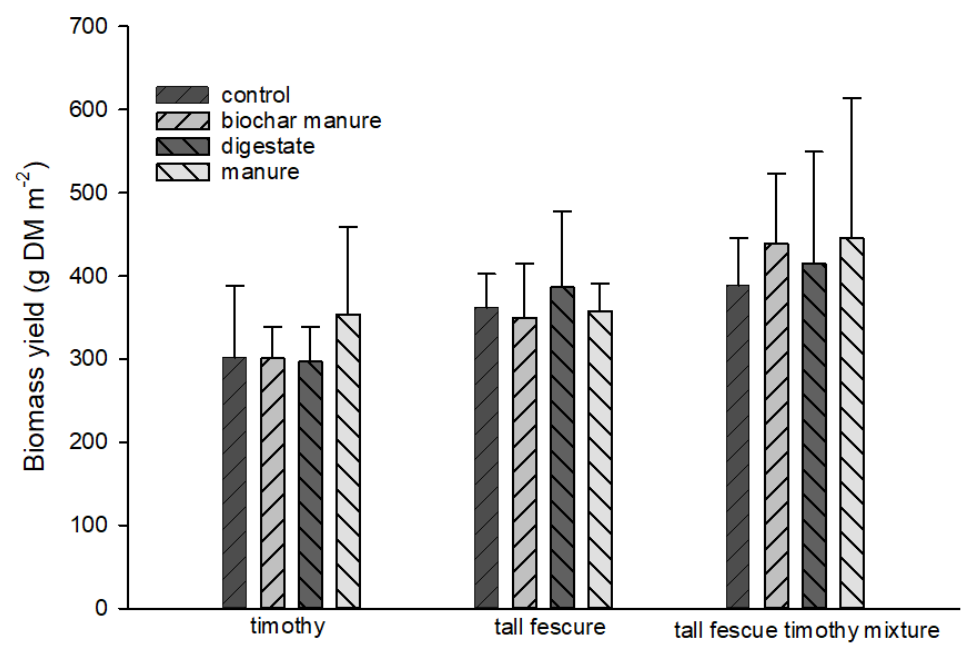

Fig. 4. Seasonal biomass yield of timothy, tall fescue and a timothy-tall fescue mixture in the four treatments at Skierniewice, Poland, in 2019. Error bars indicate $95 \%$ confidence interval.

At Særheim in March 2018, P-AL content was significantly higher in the digestate and manure treatments on the sandy loam than in the digestate and mineral fertiliser treatments on the coarse sand. P-AL content was also higher in the manure treatment on the coarse sand than in the mineral fertiliser control on that soil. K-AL content was significantly higher in all treatments on the sandy loam than the coarse sand. There were also positive effects of some organic amendments on soil K-AL content in the coarse sand compared with the mineral fertiliser control on that soil (Table 5). At Særheim in March 2019, in most of the amendment treatments, soil organic matter, P-AL and K-AL content were significantly higher in the sandy loam soil than in the coarse sand (Table 6). However, there were no clear patterns in differences in P-AL between amendments within the soils (Table 6). There were also no statistically significant differences in soil organic matter and water-holding capacity between the amendment treatments at Særheim (data not shown).

\begin{tabular}{|c|c|c|c|c|c|}
\hline Amendment & TN & $\mathrm{NH}_{4}-\mathrm{N}$ & $\mathrm{NO}_{3}-\mathrm{N}$ & P-AL & K-AL \\
\hline \multicolumn{6}{|l|}{ Sandy loam } \\
\hline Control & $1.0 \mathrm{~A}( \pm 0.14)$ & $4.7 \mathrm{~A}( \pm 1.4)$ & 0.76 B $( \pm 0.11)$ & $45.7 \mathrm{AB}( \pm 0.88)$ & $63.9 \mathrm{~A}( \pm 1.2)$ \\
\hline Manure + biochar & $1.1 \mathrm{~A}( \pm 0)$ & $6.1 \mathrm{~A}( \pm 1.7)$ & $2.0 \mathrm{~A}( \pm 0.62)$ & $53.7 \mathrm{AB}( \pm 13.3)$ & $80.4 \mathrm{~A}( \pm 1.0)$ \\
\hline Digestate & $1.2 \mathrm{~A}( \pm 0.14)$ & $6.4 \mathrm{~A}( \pm 0.46)$ & $0.94 \mathrm{AB}( \pm 0.021)$ & $76.7 \mathrm{~A}( \pm 8.3)$ & $76.5 \mathrm{~A}( \pm 4.4)$ \\
\hline Manure & $1.15 \mathrm{~A}( \pm 0.071)$ & $6.4 \mathrm{~A}( \pm 0.17)$ & $0.86 \mathrm{AB}( \pm 0.28)$ & $74.2 \mathrm{~A}( \pm 3.0)$ & 74.4 A ( \pm 9.4$)$ \\
\hline \multicolumn{6}{|l|}{ Coarse sand } \\
\hline Control & $0.2 \mathrm{~B}( \pm 0)$ & $0.56 \mathrm{~B}( \pm 0.021)$ & 0.56 B $( \pm 0.021)$ & $14.2 \mathrm{C}( \pm 0.14)$ & $14.2 \mathrm{C}( \pm 0.14)$ \\
\hline Manure + biochar & $0.25 \mathrm{~B}( \pm 0.071)$ & $0.54 \mathrm{~B}( \pm 0)$ & $0.97 \mathrm{AB}( \pm 0.44)$ & $37.7 \mathrm{ABC}( \pm 10.1)$ & 37.7 B $( \pm 0.60)$ \\
\hline Digestate & 0.3 B $( \pm 0)$ & 0.57 B $( \pm 0.014)$ & 0.57 B ( \pm 0.014$)$ & $32.3 \mathrm{BC}( \pm 15.8)$ & $28.7 \mathrm{BC}( \pm 10.7)$ \\
\hline Manure & $0.35 \mathrm{~B}( \pm 0.071)$ & 0.525 B $( \pm 0.0071)$ & $0.525 \mathrm{~B}( \pm 0.0071)$ & 60.9 AB $( \pm 16.4)$ & 39.3 B ( \pm 5.8$)$ \\
\hline Standard error & 0.083 & 0.79 & 0.29 & 10.5 & 5.7 \\
\hline
\end{tabular}

Before the experiment, the soil at Skierniewice was characterised by low SOM, TN, P and K content (Table 1). The

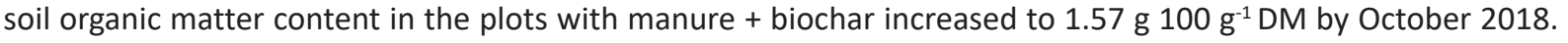
There was no significant effect of the other amendments on soil organic $C$, and no significant effect of any of the amendments on total organic nitrogen, P-AL or K-AL (data not shown). 
Table 6. Amount of Kjeldahl nitrogen (TN) $\left(\mathrm{g} \mathrm{kg}^{-1} \mathrm{DM}\right), \mathrm{NH} 4-\mathrm{N}\left(\mathrm{NH}_{4}-\mathrm{N}, \mathrm{mg} \mathrm{kg}^{-1} \mathrm{DM}\right)$, nitrate- $\mathrm{N}\left(\mathrm{NO}_{3}-\mathrm{N}, \mathrm{mg} \mathrm{kg}^{-1} \mathrm{DM}\right)$, plantavailable phosphorus (P-AL) and potassium (K-AL) (mg kg-1 DM), and soil organic matter (SOM, $\left.\mathrm{g} \mathrm{kg}^{-1} \mathrm{DM}\right)$ in the Særheim plots that received different amendments in March 2019 ( \pm 1 standard deviation for each amendment and soil combination is given within parenthesis). Different letters within columns indicate statistically significant differences $(p<0.05)$.

\begin{tabular}{lcccccc}
\hline Amendment & \multicolumn{1}{c}{$\mathrm{TN}$} & $\mathrm{NH}_{4}-\mathrm{N}$ & $\mathrm{NO}_{3}-\mathrm{N}$ & $\mathrm{P}-\mathrm{AL}$ & $\mathrm{K}-\mathrm{AL}$ & $\mathrm{SOM}$ \\
\hline Sandy loam & & & & & & \\
Control & $3.45 \mathrm{~A}( \pm 0.49)$ & $2.75 \mathrm{~A}( \pm 0.071)$ & $11.0 \mathrm{AB}( \pm 2.4)$ & $54 \mathrm{BCD}( \pm 1.4)$ & $71 \mathrm{~A}( \pm 9.9)$ & $67 \mathrm{~A}( \pm 5.7)$ \\
Manure + biochar & $3.8 \mathrm{~A}( \pm 0.21)$ & $2.2 \mathrm{~A}( \pm 1.7)$ & $14.4 \mathrm{~A}( \pm 0.35)$ & $76.5 \mathrm{~A}( \pm 6.4)$ & $76.5 \mathrm{~A}( \pm 3.5)$ & $76.5 \mathrm{~A}( \pm 0.71)$ \\
Digestate & $3.7 \mathrm{~A}( \pm 0.21)$ & $3.6 \mathrm{~A}( \pm 0)$ & $12.1 \mathrm{~A}( \pm 3.7)$ & $69 \mathrm{AB}( \pm 7.1)$ & $76 \mathrm{~A}( \pm 2.8)$ & $67 \mathrm{~A}( \pm 4.2)$ \\
Manure & $3.15 \mathrm{~A}( \pm 0.49)$ & $3.35 \mathrm{~A}( \pm 0.21)$ & $11.2 \mathrm{AB}( \pm 1.6)$ & $71 \mathrm{AB}( \pm 5.7)$ & $83.5 \mathrm{~A}( \pm 13.4)$ & $67.5 \mathrm{~A}( \pm 0.71)$ \\
Coarse sand & & & & & & \\
Control & $0.35 \mathrm{~B}( \pm 0.071)$ & $2.15 \mathrm{~A}( \pm 1.3)$ & $1.05 \mathrm{C}( \pm 0.071)$ & $23.5 \mathrm{E}( \pm 4.9)$ & $29 \mathrm{C}( \pm 0)$ & $14 \mathrm{~B}( \pm 1.4)$ \\
Manure + biochar & $0.80 \mathrm{~B}( \pm 0)$ & $2.45 \mathrm{~A}( \pm 1.2)$ & $4.4 \mathrm{BC}( \pm 0.99)$ & $46.5 \mathrm{CD}( \pm 6.4)$ & $36.5 \mathrm{BC}( \pm 4.9)$ & $22 \mathrm{~B}( \pm 1.4)$ \\
Digestate & $0.55 \mathrm{~B}( \pm 0.071)$ & $3.0 \mathrm{~A}( \pm 0.57)$ & $2.5 \mathrm{C}( \pm 1.1)$ & $34.5 \mathrm{DE}( \pm 6.4)$ & $31.5 \mathrm{C}( \pm 2.1)$ & $14 \mathrm{~B}( \pm 2.8)$ \\
Manure & $0.70 \mathrm{~B}( \pm 0.28)$ & $3.35 \mathrm{~A}( \pm 0.30)$ & $3.6 \mathrm{C}( \pm 1.3)$ & $60.5 \mathrm{C}( \pm 2.1)$ & $49 \mathrm{ABC}( \pm 18.4)$ & $16 \mathrm{~B}( \pm 1.4)$ \\
Standard error & 0.29 & 1.8 & 1.8 & 5.4 & 9.1 & 2.9 \\
\hline
\end{tabular}

\section{Discussion}

The positive effect of the organic amendments on tall fescue and timothy biomass yield on the coarse sand soil at Særheim indicates that these materials can increase yield on soils with low organic matter and plant nutrient content in intensive production systems requiring a high supply of nutrients, under certain conditions. However, the lack of effect of organic amendments on biomass yield at Skierniewice, where the soil organic matter content was likewise low shows that this is due to other factors, such as weather factors or cultivars, that differed between the location but were not included in this study. The effects on the coarse sand soil at Særheim are in line with previous findings of positive effects of various organic soil amendments on the yield of forage grasses (Warman and Termeer 2005, Montemurro et al. 2006) and the general short-term positive effect of organic amendment on crop yield, which has been found more pronounced on soils with low organic matter content (Wortman et al. 2017).

The lack of significant effect of any of the organic amendments on biomass yield of either of the forage species on the sandy loam soil at Særheim was possibly a result of nutrient supply from the soil and mineral fertiliser at rates that did not limit plant growth even without addition of organic amendments. This supposition is based on results from previous simulations of long-term soil organic carbon effects on wheat under different $\mathrm{N}$-fertiliser regimes, where a positive effect of agronomic productivity was found with $\mathrm{N}$ fertiliser application rates up to $100 \mathrm{~kg} \mathrm{~N} \mathrm{ha}^{-1}$, but no (Ghaley et al. 2018) or only small effects at higher rates (Palmer et al. 2017). However, the difference in initial nutrient status between the two soils at Særheim was relatively small compared with the total amount of nutrients supplied by the organic amendments and the mineral fertiliser together. Therefore, the differences in amendment effect on grass biomass between the two soils could also be due to other factors than nutrient supply, such as a more positive amendment effect on water-holding capacity in the coarse sand than in the sandy loam. In a previous meta-analysis, it was found that an increase in soil organic matter content had a greater positive effect on soil water-holding capacity in sandy soils than in loams (Minasny and McBratney 2018). Although we did not find any effects of the organic amendments on soil water-holding capacity in the Særheim soils under laboratory conditions, such effects could still partly explain the difference in effects of the amendments on dry matter yield on the two soils, especially given the dry weather conditions in 2018.

The lack of significant differences in dry matter yield effects between the organic amendment treatments tested is somewhat surprising, given that the amendments differed considerably in plant nutrient and organic carbon content. It also contradicts findings in a previous greenhouse experiment, where grass species biomass responded differently to digestates (Andruschkewitsch et al. 2013) and a pot experiment, where the above-ground maize yield responded differently to different types of organic fertilizers (Gondek and Filipek-Mazur 2005). Also in previous field experiments grass species biomass responded differently to organic fertilisers which differed in properties (Warman and Termeer 2005). As speculated for the lack of organic amendment effect on the sandy loam soil, the high supply of mineral $\mathrm{N}$ may have masked any effects of differences in amendment composition on plant growth in our experiment. The lack of effect of biochar addition on soil properties also contradicts previously reported positive biochar effects on soil $\mathrm{N}$ and $\mathrm{C}$ content in nutrient-poor soils grown with unfertilised grassland 


\section{AGRICULTURAL AND FOOD SCIENCE}

T. Persson et al. (2020) 29: 482-493

(Han et al. 2016) or agricultural crops (Ohsowski et al. 2012). The greater yield of tall fescue than timothy in both soils at Særheim and the greater difference between the biomass of these two species in 2018 on the coarse sand soil than on the sandy loam soil at Særheim could be a combined effect of the dry conditions and morphological differences between the species. Timothy normally has a larger proportion of root biomass allocated to shallow soil layers than tall fescue (Bolinder et al. 2002). Given the visible drought symptoms on the coarse sand soil and its lower water-holding capacity than the sandy loam, it is clear that there was relatively less plant-available water in the former soil than in the latter during 2018. In a previous controlled greenhouse experiment by Eneji et al. (2008), the effect of drought was relatively stronger on timothy dry matter than on tall fescue dry matter, which further supports the assumption that the soil effect on biomass production by the two species was due to different degrees of drought stress. The dry conditions, with precipitation well below normal, during the growing season in 2018 at both locations probably also explain the higher tall fescue yield than timothy yield on the sandy loam soil at Særheim. The relative larger effect of organic amendments on grassland productivity on the coarse soil than on the finer-textured soils could also mean that allocating a disproportionally larger fraction of soil amendment materials to coarser soils could potentially have a greater positive effect on grassland productivity than uniform allocation among soil types within a farm or production region with heterogeneous soils. More experiments under a wider range of soil, climate conditions and management practices need to be carried out to further investigate the advantages of such soil-texture based application regimes.

The lack of difference in dry matter yield between the manure and digestate treatments in our study, indicates that changes in nutrient composition during anaerobic digestion do not negatively impacts the effect of amendment on grassland biomass in systems with high nutrient turnover. However, if less mineral fertiliser had been supplied, the nutrient composition of the amendment might have affected grassland dry matter yield, as shown in a previous experiment (Šimon et al. 2015). Some, but not all, of the studies reviewed by Möller and Müller (2012) reported a positive effect of anaerobic digestion of animal manure on crop and grassland yields. In a study comparing the effects of raw cattle manure and separated digestate at similar $\mathrm{N}$ supply rates, no differences in forage barley biomass yield were found between these two treatments (Chiyoka et al. 2014). However, it is difficult to compare our results with those of the many studies using unseparated digestate and manure with different nutritive and physical properties from the dry fraction of separated manure and digestate used here.

\section{Conclusions}

A positive effect of incorporation of organic materials on biomass yield of forage grasses was observed on a coarse sand soil with low initial organic matter and plant nutrient content, under intensive production conditions with a large supply of nutrients. At the application rates used here, addition of raw biochar together with undigested manure did not affect the yield of the grasses or the water-holding properties of the soils.

\section{Acknowledgements}

This study was conducted within the FACCE-SURPLUS project 'INTENSE'. Financial support was provided by the Norwegian Research Council and the National Centre of Research and Development in Poland, through the FACCEJPI programme SFS-05-2015: 'Strategies for crop productivity, stability and quality'.

\section{References}

Al Seadi, T., Drosg, B., Fuchs, W., Rutz, D. \& Janssen, R. 2013. Biogas digestate quality and utilization. In: Wellinger, A., Murphy, J. \& Baxter, D. (eds). The Biogas Handbook Science, Production and Applications. Sawston, Cambridge, UK: Woodhead Publishing, p. 267-301. https://doi.org/10.1533/9780857097415.2.267

Andruschkewitsch, M., Wachendorf, C. \& Wachendorf, M. 2013. Effects of digestates from different biogas production systems on above and belowground grass growth and the nitrogen status of the plant-soil-system. Grassland Science 59: $183-195$. https://doi.org/10.1111/grs.12028

Biederman, L.A. \& Harpole, W.S. 2013. Biochar and its effects on plant productivity and nutrient cycling: a meta-analysis. GCB Bioenergy 5: 202-214. https://doi.org/10.1111/gcbb.12037

Bolinder, M.A., Angers, D.A., Bélanger, G., Michaud, R. \& Laverdière, M.R. 2002. Root biomass and shoot to root ratios of perennial forage crops in eastern Canada. Canadian Journal of Plant Science 82: 731-737. https://doi.org/10.4141/P01-139

Cameron, K.C., Di, H.J. \& Moir, J.L. 2013. Nitrogen losses from the soil/plant system: a review. Annals of Applied Biology 162: 145-173. https://doi.org/10.1111/aab.12014

Chiyoka, W.L., Zvomuya, F. \& Hao, X. 2014. A bioassay of nitrogen availability in soils amended with solid digestate from anaerobically digested beef cattle feedlot manure. Soil Science Society of America Journal 78: 1291-1300.

https://doi.org/10.2136/sssaj2013.01.0030 
Egnér, H., Riehm, H. \& Domingo, W.R. 1960. Untersuchungen über die chemische Bodenanalyse als Grundlage für die Beurteilung des Nährstoffzustandes der Böden. II Chemische Extrationsmethoden zur Phosphor und Kaliumbestimmung. Kungliga Lantbrukshögskolans Annaler 26: 199-215.

Eneji, A.E., Inanaga, S., Muranaka, S., Li, J., Hattori, T., An, P. \& Tsuji, W. 2008. Growth and nutrient use in four grasses under drought stress as mediated by silicon fertilizers. Journal of Plant Nutrition 31: 355-365. https://doi.org/10.1080/01904160801894913

Fu, J., Gasche, R., Wang, N., Lu, H., Butterbach-Bahl, K. \& Kiese, R. 2017. Impacts of climate and management on water balance and nitrogen leaching from montane grassland soils of S-Germany. Environmental Pollution 229: 119-131. https://doi.org/10.1016/j.envpol.2017.05.071

Fulkerson, W.J., Neal, J.S., Clark, C.F., Horadagoda, A., Nandra, K.S. \& Barchia, I. 2007. Nutritive value of forage species grown in the warm temperate climate of Australia for dairy cows: Grasses and legumes. Livestock Science 107: 253-264. https://doi.org/10.1016/j.livsci.2006.09.029

Ghaley, B.B., Wösten, H., Olesen, J.E., Schelde, K., Baby, S., Karki, Y.K., Børgesen, C.D., Smith, P., Yeluripati, J. \& Ferrise, R. 2018. Simulation of soil organic carbon effects on long-term winter wheat (Triticum aestivum) production under varying fertilizer inputs. Frontiers in Plant Science 9: 1158. https://doi.org/10.3389/fpls.2018.01158

Gondek, K. \& Filipek-Mazur, B. 2005. The effects of mineral treatment and the amendmentsby organic and organomineral fertilisers on the crop yield, plant nutrient status and soil properties. Plant, Soil and Environment 51: 34-45. https://doi.org/10.17221/3553-PSE

Gundersen, G.I. \& Heldal, J. 2015. Bruk av gjødselressurser i jordbruket 2013. Metodebeskrivelse og resultater fra en utvalgsbasert undersøkelse. Rapporter. Statistics Norway, Oslo-Kongsvinger. 84 p.

Han, F., Ren, L. \& Zhang, X.-C. 2016. Effect of biochar on the soil nutrients about different grasslands in the Loess Plateau. CATENA 137: 554-562. https://doi.org/10.1016/j.catena.2015.11.002

Jeffery, S., Verheijen, F.G., van der Velde, M. \& Bastos, A.C. 2011. A quantitative review of the effects of biochar application to soils on crop productivity using meta-analysis. Agriculture, Ecosystems \& Environment 144: 175-187.

https://doi.org/10.1016/j.agee.2011.08.015

Karhu, K., Mattila, T., Bergström, I. \& Regina, K. 2011. Biochar addition to agricultural soil increased CH uptake and water holding capacity - Results from a short-term pilot field study. Agriculture, Ecosystems \& Environment 140: 309-313. https://doi.org/10.1016/j.agee.2010.12.005

Lehmann, J., Gaunt, J. \& Rondon, M. 2006. Bio-char sequestration in terrestrial ecosystems-a review. Mitigation and Adaptation Strategies for Global Change 11: 403-427. https://doi.org/10.1007/s11027-005-9006-5

Losak, T., Hlusek, J., Zatloukalova, A., Musilova, L., Vitezova, M., Skarpa, P., Zlamalova, T., Fryc, J., Vitez, T. \& Marecek, J. 2014. Digestate from biogas plants is an attractive alternative to mineral fertilisation of kohlrabi. Journal of Sustainable Development of Energy, Water and Environment Systems 2: 309-318. https://doi.org/10.13044/j.sdewes.2014.02.0025

Maire, V., Gross, N., Da Silveira Pontes, L., Picon-Cochard, C. \& Soussana, J.-F. 2009. Trade-off between root nitrogen acquisition and shoot nitrogen utilization across 13 co-occurring pasture grass species. Functional Ecology 23: 668-679. https://doi.org/10.1111/j.1365-2435.2009.01557.x

Major, J. 2010. Guidelines on practical aspects of biochar application to field soil in various soil management systems. Canandaigua, NY, USA: International Biochar Initiative. 23 p.

Manyà, J.J. 2012. Pyrolysis for biochar purposes: a review to establish current knowledge gaps and research needs. Environmental Science \& Technology 46: 7939-7954. https://doi.org/10.1021/es301029g

Marmiroli, M., Imperiale, D., Lencioni, G., Mussi, F., Marmiroli, N. \& Maestri, E. 2018. Structural and functional features of chars from different biomasses as potential plant amendments. Frontiers in Plant Science 9: Article 1119. https://doi.org/10.3389/fpls.2018.01119

Masunga, R.H., Uzokwe, V.N., Mlay, P.D., Odeh, I., Singh, A., Buchan, D. \& De Neve, S. 2016. Nitrogen mineralization dynamics of different valuable organic amendments commonly used in agriculture. Applied Soil Ecology 101: 185-193. https://doi.org/10.1016/j.apsoil.2016.01.006

Minasny, B. \& McBratney, A.B. 2018. Limited effect of organic matter on soil available water capacity. European Journal of Soil Science 69: 39-47. https://doi.org/10.1111/ejss.12475

Ministry of Agriculture and Food, Ministry of Climate and Environment, \& Ministry of Health and Care Services 2003. Forskrift om gjødselvarer mv. av organisk opphav, FOR-2003-07-04-951. Lovdata, Oslo, Norway.

Möller, K. \& Müller, T. 2012. Effects of anaerobic digestion on digestate nutrient availability and crop growth: A review. Engineering in Life Sciences 12: 242-257. https://doi.org/10.1002/elsc.201100085

Montemurro, F., Maiorana, M., Convertini, G. \& Ferri, D. 2006. Compost organic amendments in fodder crops: Effects on yield, nitrogen utilization and soil characteristics. Compost Science \& Utilization 14: 114-123. https://doi.org/10.1080/1065657X.2006.10702272

Nguyen, T.L.T. \& Hermansen, J.E. 2015. Life cycle environmental performance of miscanthus gasification versus other technologies for electricity production. Sustainable Energy Technologies and Assessments 9: 81-94. https://doi.org/10.1016/j.seta.2014.12.005

Ohsowski, B.M., Klironomos, J.N., Dunfield, K.E. \& Hart, M.M. 2012. The potential of soil amendments for restoring severely disturbed grasslands. Applied Soil Ecology 60: 77-83. https://doi.org/10.1016/j.apsoil.2012.02.006

Palmer, J., Thorburn, P.J., Biggs, J.S., Dominati, E.J., Probert, M.E., Meier, E.A., Huth, N.I., Dodd, M., Snow, V. \& Larsen, J.R. 2017. Nitrogen cycling from increased soil organic carbon contributes both positively and negatively to ecosystem services in wheat agro-ecosystems. Frontiers in Plant Science 8: 731. https://doi.org/10.3389/fpls.2017.00731 


\section{AGRICULTURAL AND FOOD SCIENCE}

T. Persson et al. (2020) 29: 482-493

Reynolds, S. 1970. The gravimetric method of soil moisture determination Part IA study of equipment, and methodological problems. Journal of Hydrology 11: 258-273. https://doi.org/10.1016/0022-1694(70)90066-1

Schimmelpfennig, S., Müller, C., Grünhage, L., Koch, C. \& Kammann, C. 2014. Biochar, hydrochar and uncarbonized feedstock application to permanent grassland-Effects on greenhouse gas emissions and plant growth. Agriculture, Ecosystems \& Environment 191: 39-52. https://doi.org/10.1016/j.agee.2014.03.027

Schröder, J. 2005. Revisiting the agronomic benefits of manure: a correct assessment and exploitation of its fertilizer value spares the environment. Bioresource Technology 96: 253-261. https://doi.org/10.1016/j.biortech.2004.05.015

Simpson, R.J., Richardson, A.E., Nichols, S.N. \& Crush, J.R. 2014. Pasture plants and soil fertility management to improve the efficiency of phosphorus fertiliser use in temperate grassland systems. Crop and Pasture Science 65: 556-575. https://doi.org/10.1071/CP13395

Šimon, T., Kunzová, E. \& Friedlová, M. 2015. The effect of digestate, cattle slurry and mineral fertilization on the winter wheat yield and soil quality parameters. Plant, Soil and Environment 61: 522-527. https://doi.org/10.17221/530/2015-PSE

Sosulski, T., Szara, E. \& Stępień, W. 2013: Dissolved organic carbon in Luvisol under different fertilization and crop rotation. Soil Science Annual 64: 114-119. https://doi.org/10.2478/ssa-2013-0015

Tambone, F., Scaglia, B., D'Imporzano, G., Schievano, A., Orzi, V., Salati, S. \& Adani, F. 2010. Assessing amendment and fertilizing properties of digestates from anaerobic digestion through a comparative study with digested sludge and compost. Chemosphere 81: 577-583. https://doi.org/10.1016/j.chemosphere.2010.08.034

Thomsen, I.K. 2005. Crop N utilization and leaching losses as affected by time and method of application of farmyard manure. European Journal of Agronomy 22: 1-9. https://doi.org/10.1016/j.eja.2003.10.008

Thornton, P.K. 2010. Livestock production: recent trends, future prospects. Philosophical Transactions: Biological Sciences 365: 2853-2867. https://doi.org/10.1098/rstb.2010.0134

Valkama, E., Lemola, R., Känkänen, H. \& Turtola, E. 2015. Meta-analysis of the effects of undersown catch crops on nitrogen leaching loss and grain yields in the Nordic countries. Agriculture, Ecosystems \& Environment 203: 93-101. https://doi.org/10.1016/j.agee.2015.01.023

Valkama, E., Virkajärvi, P., Uusitalo, R., Ylivainio, K. \& Turtola, E. 2016. Meta-analysis of grass ley response to phosphorus fertilization in Finland. Grass and Forage Science 71: 36-53. https://doi.org/10.1111/gfs.12156

Walsh, J.J., Jones, D.L., Edwards-Jones, G. \& Williams, A.P. 2012. Replacing inorganic fertilizer with anaerobic digestate may maintain agricultural productivity at less environmental cost. Journal of Plant Nutrition and Soil Science 175: 840-845. https://doi.org/10.1002/jpln.201200214

Warman, P.R. \& Termeer, W.C. 2005. Evaluation of sewage sludge, septic waste and sludge compost applications to corn and forage: yields and N, P and K content of crops and soils. Bioresource Technology 96: 955-961. https://doi.org/10.1016/j.biortech.2004.08.003

Webb, J., Pain, B., Bittman, S. \& Morgan, J. 2010. The impacts of manure application methods on emissions of ammonia, nitrous oxide and on crop response-A review. Agriculture, Ecosystems \& Environment 137: 39-46. https://doi.org/10.1016/j.agee.2010.01.001

Wortman, S.E., Holmes, A.A., Miernicki, E., Knoche, K. \& Pittelkow, C.M. 2017. First-Season Crop Yield Response to Organic Soil Amendments: A Meta-Analysis. Agronomy Journal 109: 1210-1217. https://doi.org/10.2134/agronj2016.10.0627

Zebarth, B.J., Neilsen, G.H., Hogue, E. \& Neilsen, D. 1999. Influence of organic waste amendments on selected soil physical and chemical properties. Canadian Journal of Soil Science 79: 501-504. https://doi.org/10.4141/S98-074 